\title{
HISTORY AND ORGANIZATION OF COURTS SYSTEM IN NIGERIA
}

\section{O. O. OGWEZZY}

\section{Oluwatosin O. Ogwezzy}

Faculty of Law

AdekunleAjasin University, Akungba-Akoko, Nigeria

LL.B (OlabisiOnabanjo University, Nigeria), LL.M (Lagos, Nigeria),

B.L (Enugu, Nigeria)

Email: ogwezzytosin@gmail.com

Telephone: +2348033273670

\section{ABSTRACT \\ A Court is a place where justice is administered or where atrial is held. Although it may be argued that this definition is deficient in the sense that courts are sometimes distinguished from other bodies such as tribunals, which are also concerns with settling legal disputes, however, the definition conveys the meaning intended for this work. This paper seeks to discuss the brief history of court system in Nigeria, its organization, jurisdictions, functions.}

KEYWORDS: Court, Jurisdiction, Procedure, Rules, Constitution.

\section{INTRODUCTION.}

Courts may simply be defined as places concerned with settling legal disputes. ${ }^{1}$ The hierarchy of courts in Nigeria is as contained in Section6(5) of the Constitution of the Federal Republic of Nigeria( as amended).The said section specifically lists the courts which are also established under chapter VII of the constitution. These are known as the superior courts of records .In addition to the superior records, the constitution also empowers the National Assembly and state Houses of Assembly to establish courts of law, to exercise Jurisdiction, whether Original or appellate in respect of their respective legislative competences. ${ }^{2}$ These are inferior courts of records.

\section{CLASSIFICATION OF COURTS.}

Under the Nigerian legal system there are large number of courts which vary from small courts with limited jurisdiction over a particular geographical area or a particular type of dispute, to courts which can hear any case about virtually any aspect of law. They can be grouped together in a number of ways. Traditionally, it has been said that the "two fundamental divisions of English courts are;

(1) Courts of records and courts not of record;

(2) Superior and Inferior courts ${ }^{3}$

The superior courts of records provided for under the constitution are:

(a) The Supreme Court of Nigeria

(b) The Court of Appeal

(c) The Federal High court

(d) National Industrial Court ${ }^{4}$

\footnotetext{
${ }^{1}$ AdewaleTaiwo; The Principles,Practice and Procedure of Civil Litigation in Nigeria.Ababa press Limited.2015 p.51.

Section 6(5)(j) and k.see D.I Efevwerhan;Principles of Civil Procedure in Nigeria.Snaap Press Limited ,Enugu. $2^{\text {nd }}$ edn)p.22

${ }^{3}$ Walker,R.\&Ward,R, Walker and Walker's English Legal system, $7^{\text {th }}$ ed(Butterworhss London 1994)140.See Adewaletaiwo ,op.cit .p.52
} 


\section{HISTORY AND ORGANIZATION OF COURTS SYSTEM IN NIGERIA}

(e) The high Court of Federal Capital Territory, Abuja

(f) A High Court of a State

(g) The sharia court of Appeal of the Federal Capital Territory, Abuja

(h) A sharia Court Appeal of a state

(i) The Customary Court of Appeal of the Federal Capital Territory, Abuja

(j) A customary Court of Appeal of a State.

The inferior courts of record that have been established or deemed established by the legislative bodies above are:

(a)Magistrates' courts

(b)Districts Courts

(c) Sharia courts

(d)Area Courts

(e) Customary Courts

We shall now examine each courts seriatim beginning with the superior courts.

\section{SUPREME COURT OF NIGERIA}

This is the apex court of the nation, Nigeria established under section 230 of the 1999 constitution. It consists of the chief justice of Nigeria who is the head of the court and such number of justices of Supreme Court, not exceeding twenty -one as may be prescribed by an act of National Assembly. The court has both original and appellate jurisdiction. ${ }^{5}$

\section{COURT OF APPEAL}

The Court of Appeal was established on $1^{\text {st }}$ October, $1976 .^{6}$ The Court was established to serve as an immediate court between the high court and other subordinates courts and the Supreme Court.Under the 1999 constitution, the Court of Appeal is established under Section.237.It is headed by the president of the Court of Appeal. The Court consists of the president and such number of justices of the court of appeal, not less than forty-nine of which not less than three shall be learned in Islamic law ; and not less than three shall be learned in customary law, as may be prescribed by an Act of the National Assembly. The court of Appeal has both Original and Appellate Jurisdiction as stated in the constitution. ${ }^{7}$

\section{FEDERAL HIGH COURT}

The Federal High Court was initially established as the Federal Revenue Court in $1973{ }^{8}$ Now the Federal High Court under Section 249 of the 1999 constitution. The Court is headed by a Chief Judge of the Federal High court.The Federal High Court consists of the Chief Judge and such number of Judges of theFederal High Court as may be prescribed by an Act of the National Assembly. ${ }^{9}$ The Jurisdiction of the Federal High Court was originally provided under Section 7 of the Federal Revenue Court Act 1973.In terms of section 251(1) of the 1999 Nigerian Constitution, the Federal High Court shall have and exercise jurisdiction to the exclusion of any other court in civil causes and matters arising from (a)to (r).

\section{STATE HIGH COURT}

By virtue of section 270 of the 1999 Nigerian Constitution, each of the 36 states of the Federation shall have its own high court consisting of a Chief Judge and such number of

\footnotetext{
${ }^{4}$ Inserted by virtue of section 2, constitution of the federal republic of Nigeria(Third Alteration)Act 2010.See D.I Efevwerhan ,op.cit. p.22

${ }^{5}$ Section 232 and 233 of the Constitution of the Federal Republic of Nigeria(As Amended)

${ }^{6}$ See the Constitution of the Federation,(the Constitution Amendment)(No.2),decree No.42.1976.

${ }^{7}$ Section 239 and 240 of the Constitution of the Federal Republic of Nigeria(As Amended)

${ }^{8}$ Section 1 of the Federal Revenue Court Act 1973.

${ }^{9}$ S.249(2) of 1999 Constitution.see,however,s.1(2)(b) of Cap F12,LFN 2004, which prescribes 50 judges for the Federal High Court in addition to the Chief Judge.
} 
judges as may be prescribed by a law of the house of Assembly of a state. The structure, organization and jurisdiction of the various state High Courts are generally uniform since they all derive their powers from a single source that is the constitution.

\section{THE HIGH COURT OF THE FEDERAL CAPITAL TERRITORY, ABUJA}

The Constitution provides for the establishment of a high court of the federal Capital territory Abuja. ${ }^{10}$ The High court of the FCT shall consist of a Chief Judge and such number of judges as may be prescribed by an Act of the National Assembly.It has jurisdiction to hear and determine any civil proceedings in which the existence or extent of a legal right, power duty,liability,privilege,interest,obligation or claim is in issue or to hear and determine any criminal proceedings involving or relating to any penalty,forfeiture,punishment or other liability in respect of an offence committed by any person. ${ }^{11}$

\section{NATIONAL INDUSTRIAL COURT}

Originally, the industrial court(Nic) was established in 1976 for the purpose of dealing with trade disputes and collective agreements ${ }^{12}$.The court isnow included in the lists of courts recognized under section section 6 of the 1999 constitution of the Federal Republic of Nigeria (third Alteration) Act of $2010 .{ }^{13}$ The Act provides for the establishment of the National Industrial Court,and states that the court shall consist of the president of National Industrial Court and such number of judges of the court as may be prescribed by an Act of the National Assembly. ${ }^{14}$

An examination of the provision of section $254 \mathrm{C}$ (1) of the 1999Constitution (as amended) shows that the National Industrial Court enjoys a considerable Jurisdiction on a number of items relating to labour matters. There are innovations to this court .It has only one Jurisdiction and processes can be filed in one state and heard in another state.

\section{THE SHARIA COURT OF APPEAL}

The Constitution provides for the establishment of the Sharia Court of Appeal of the FederalCapital Territory,Abuja ${ }^{15}$ and of a State ${ }^{16}$.The Court consists of Grand kadi, and such number of Kadis as may be prescribed by the National assembly or House Assembly of a state as the case may be. ${ }^{17}$ The sharia court of appeal is a superior court of Record which hears appeals from the sharia court and Area court in cases involving Islamic personal law. ${ }^{18}$

\section{THE CUSTOMARY COURT OF APPEAL}

The Constitution provides for the establishment of the Customary Court of Appeal of the Federal Capital Territory,Abuja ${ }^{19}$ and of the State. ${ }^{20}$ The Court consists of a president, and such number of the judges of Customary Court of Appeal as may be prescribed by the National Assembly or House of Assembly of a State as the case may be. ${ }^{21}$ The Customary Court of Appeal is a court of superior record, and shall exercise appellate and supervisory jurisdiction in civil proceedings involving questions of customary law, or such other

\footnotetext{
${ }^{10}$ Section 255 of the Constitution.(As Amended).

${ }^{11}$ Section 257 of the Constitution(As Amended).

12 Section 14 of the Trade Disputes Decree No.7 of 1976.See AdewaleTaiwoop.cit p.68

13 Act No.3 of 2010.It was passed by the senate of the National Assembly on 14 December, 2010House of representatives on 15 December ,2010 the report of approvals by the states Houses of Assembly was received on 8 February,2011.The president gave assent to it on 4 March,2011, a date which Act commenced operation..

${ }^{14}$ Section 254A(2) of the 1999 Constitution.(As Amended).

${ }^{15}$ Section 260 of the Constitution.

${ }^{16}$ Section 275 of the Constitution.

${ }^{17}$ Sections 260(2)\&275(2) of the Constitution.

${ }^{18}$ Section 262(1) \& Section 277(1) of the Constitution.

${ }^{19}$ Section 265 of the Constitution,

${ }^{20}$ Section 280 of the Constitution.

${ }^{21}$ Sections 265(2)\&280(2) of the Constitution.
} 
jurisdiction as may be conferred upon it by the National Assembly or the State house of assembly as the case may be. ${ }^{22}$

\section{ELECTION TRIBUNALS}

The 1999 Constitution(as amended) states that there shall be established for the each State of the Federation and the Federal Capital Territtory,one or more Election Tribunals to be known as National and State Houses of Assembly Election Tribunals which shall, to the exclusion of any court or tribunal, have original jurisdiction to hear and determine petitions as to whether-(a)any person has been validly elected as a member of the National Assembly;(b)any person has been validly elected as a member of the House of Assembly of a state. ${ }^{23}$ Also there shall be established in each state of the federation, one or more tribunals to be known as the Governorship Election Tribunals which shall, to the exclusion of any court or tribunal, have original Jurisdiction to hear and determine petitions as to whether any person has been validly elected to the office of the Governor or the Deputy Governor of a state. ${ }^{24}$

\section{MAGISTRATES COURTS AND DISTRICTS COURTS}

Magistrates Courts are Courts of Summary Jurisdiction created by law of the House of Assembly of a State. They are called Courts of Summary Jurisdiction because matters are determined therein without pleadings or briefs by parties. ${ }^{25}$

\section{AREA COURTS, SHARIACOURTS AND CUSTOMARY COURTS}

Area courts and Customarycourts areestablished essentially for the administration of customary and native law in Nigeria.The term area court is used in Northern Nigeria while the term customary law is used to denote same court in southern Nigeria. The various statesin Southern Nigeria have Customary Courts.Customary Court is constituted by president and at least, two or other four members as the case may be. The Courts are usually constituted by a judge called area court Judge sitting alone or with one or more members. ${ }^{26}$ It should be noted that customary and Area courts have jurisdictions only to Nigerians. ${ }^{27}$ Customary and Area courts are subject to general supervision of high court. Area and Customary courts are not empowered to issue order of mandamus, certiorari, prohibition, injunctions and quo warranto.

\section{CONCLUSION}

The paper has examined the various courts starting from the top of thehierarchy in Nigeria, thatis, theSupreme Court of Nigeria down to the lowest, which are the Area and Customary Courts. The jurisdictions and functions of these various courts were also examined.

\section{BIBLIOGRAPHY.}

1. AdewaleTaiwo; The Principles, Practice and Procedure of Civil Llitigation in Nigeria.Ababa press Limited.2015

2. Constitution of the Federal Republic of Nigeria(As Amended)

3. D.I Efevwerhan;Principles of Civil Procedure in Nigeria.Snaap Press Limited ,Enugu. $2^{\text {nd }}$ edn

\footnotetext{
${ }^{22}$ Sections267\&282 of the Constitution.

${ }^{23}$ See Section 9(1) of the Constitution of the Federal Republic of Nigeria( second Alteration)Act No.2,2010.

${ }^{24}$ Section 9 (2) of the Constitution of the Federal Republic of Nigeria ( second Alteration)Act No 2.,2010.,see also section 285(2)of the Constitution.

${ }^{25}$ D.I Efevwerhan,op.cit, p.92

${ }^{26}$ See generally sec 16-20,Customary courts law(CAP33) Laws of Ondo state 1978. See Adewale Taiwo op.cit.p. 82

${ }^{27}$ See Section 16 Customary Laws of Ondo state.
} 